\title{
EVALUATION OF ROOTSTOCKS FOR THE ‘VERDEJO NEGRO’ CULTIVAR
}

\section{AVALIAÇÃO DE PORTA-ENXERTOS PARA A CULTIVAR 'VERDEJO NEGRO’}

\author{
María Dolores Loureiro ${ }^{1 *}$, Paula Moreno-Sanz ${ }^{2,3}$, Belén Suárez ${ }^{1}$ \\ ${ }^{1}$ Servicio Regional de Investigación y Desarrollo Agroalimentario (SERIDA), Área de Tecnología de los Alimentos, Ctra. AS-267, PK 19. 33300 \\ Villaviciosa, Asturias, Spain. \\ ${ }^{2}$ Fondazione Edmund Mach, Research and Innovation Centre, Via E. Mach 1, 38010 San Michele all'Adige (TN), Italy. \\ ${ }^{3}$ Center Agriculture Food and Environment (C3A), University of Trento, Via E. Mach 1, 38010 San Michele all'Adige (TN), Italy. \\ *Corresponding author. Tel.: +34 9858900 66, e-mail: mdolorlr@serida.org
}

(Received 25.10.2019. Accepted 06.10.2020)

\section{SUMMARY}

Grapevine (Vitis vinifera L.) cultivation in Asturias (Northwestern Spain) was on the brink of extinction in the last century. Nevertheless, the present century is witnessing its rebound as a consequence of the recognition of the Cangas Wine Designation of Origin. The long period of abandonment has resulted in a lack of information about the most suitable rootstocks for the attainment of optimal quality. In this study, the agronomical and oenological parameters of the 'Verdejo Negro' cultivar grafted on three rootstocks ('196-17 C', '101-14 MG' and '3309 C') were studied. Three repetitions of ten vines for each rootstock were disposed in a completely randomized design. Agronomical (phenology, yield, pruning weight and Ravaz index) and enological (berry, must and wine composition) parameters were measured, and the elaborated wines were sensorially evaluated. Concerning phenology, the '101-14 MG' rootstock advanced the veraison in the last two years of the study. The year significantly influenced many of the agronomical and enological parameters, whereas the rootstock only affected the Weaver index, which was higher for the '101-14 MG' rootstock, indicating a more advanced maturation with this rootstock, and at the wine volatile acidity, higher for ' 3309 $\mathrm{C}$ ' wines. When the wines of 'Verdejo Negro' grafted on the three studied rootstocks were sensorially evaluated, few differences were found. Wines from '101-14 MG' scored slightly better for nose parameters, although the overall judgment was very similar for all the wines. Considering the small effect of the rootstocks on the wines of 'Verdejo Negro', there is no clear recommendation at present. But it is important to take into account the effects of climate change, since the advance of maturation induced by the ' $101-14$ MG' rootstock may hinder the production of balanced wines of the 'Verdejo Negro' cultivar in the future. The predicted earlier ripening may lead to grapes with excessive sugar level, low acidity and a decoupling of phenolic and technological maturity.

\section{RESUMO}

A cultura da videira (Vitis vinifera L.) nas Astúrias (Noroeste da Espanha) esteve à beira da extinção no último século. No entanto, o presente século testemunha a sua recuperação como consequência do reconhecimento da Denominação de Origem do Vinho de Cangas. O longo tempo de abandono tem originado uma falta de informação sobre os porta-enxertos mais adequados para a obtenção da qualidade ótima. Neste trabalho foram estudados parâmetros agronómicos e enológicos da cultivar 'Verdejo Negro' enxertada em três porta-enxertos ('196-17 C', '101-14 MG' e '3309 C'). Três repetições de dez videiras para cada porta-enxerto foram dispostas em delineamento inteiramente casualizado. Foram medidos os parâmetros agronómicos (fenologia, rendimento, peso da lenha de poda e índice de Ravaz) e enológicos (composição do bago, mosto e vinho), e os vinhos elaborados foram avaliados sensorialmente. No que se refere à fenologia, o porta-enxerto '101-14 MG' antecipou o início da maturação (pintor) nos últimos dois anos do estudo. O ano influenciou significativamente muitos dos parâmetros agronómicos e enológicos analisados, enquanto o porta-enxerto afetou apenas o índice de Weaver, que foi superior para o porta-enxerto '101-14 MG', indicando uma maturação mais avançada com este porta-enxerto, e a acidez volátil, maior para os vinhos de '3309 C'. Quando os vinhos de 'Verdejo Negro' enxertados nos três porta-enxertos estudados foram avaliados sensorialmente, poucas diferenças foram encontradas. Os vinhos obtidos a partir do ' $101-14 \mathrm{MG}$ ' foram ligeiramente melhor pontuados em dois dos anos nos parâmetros nasais, embora a avaliação geral tenha sido muito semelhante para todos os vinhos. Considerando o pouco efeito dos porta-enxertos nos vinhos de 'Verdejo Negro', não há uma recomendação clara no momento. Mas é importante ter em conta os efeitos das alterações climáticas, uma vez que o avanço da maturação induzido pelo porta-enxerto '101-14 MG' pode difícultar a obtenção de vinhos equilibrados da cultivar 'Verdejo Negro' no futuro. O amadurecimento precoce previamente referido pode levar à obtenção de uvas com nível excessivo de açúcar, baixa acidez e um desacoplamento da maturidade fenólica e tecnológica.

Key words: Phenology, rootstock, Verdejo Negro, Vitis vinifera L., wine.

Palavras-chave: Fenologia, porta-enxerto, Verdejo Negro, Vitis vinifera L., vinho.

This is an Open Access article distributed under the terms of the Creative Commons Attribution License (https://creativecommons.org/licenses/by/4.0), which permits unrestricted use, distribution, and reproduction in any medium, provided the original work is properly cited. 


\section{INTRODUCTION}

The arrival of the phylloxera to Europe in the second half of the $19^{\text {th }}$ century forced to the grafting of the European grapevine cultivars on American rootstocks to guarantee the survival of this crop. Rootstocks are one of the factors of capital importance for quality in viticulture because of the additional properties that they confer to the scion such as tolerance to other pathogens, the ability to adapt to the soil and their effect on the vigor of the plant and grape composition (Whiting, 2003). Scalabrelli et al. (2003) found different performances when grafting 'Sangiovese' on twelve rootstocks and establishing the plants in two locations with different elevation, climate conditions and soil. Gutiérrez-Gamboa et al. (2019) reported differences in color and phenolic compounds in 'Merlot' wines from ungrafted vines and others grafted on eight rootstocks. Li et al. (2019) described different performances related to vigor, berry yield and quality of the 'Marselan' cultivar on eight rootstocks. Differences in $\mathrm{pH}$, yeast assimilable nitrogen and acid content in juice between 'Cabernet Sauvignon' ungrafted and grafted on seven rootstocks were observed by Xiao et al. (2020). Although each rootstock usually confers similar properties on the different scions (Marín et al., 2019), some of these effects can vary depending on the cultivar that has been grafted onto it, the soil and the climatic conditions, which underlines the importance of a previous evaluation in optimizing the performance of a cultivar in a specific site. In this sense, Alves et al. (2012) studied the effect of grafting five rootstocks with four Portuguese cultivars and also described different performances depending on the cultivar grafted. Wooldridge and Olivier (2014) evaluated the 'Merlot' cv. grafted on two rootstocks in a granitic and in a shale soil, and stated that the differential effect of rootstock on some parameters, such as the pruning weight or the astringency of wines, was more pronounced in one soil than in the other one. Clingeleffer et al. (2019) registered significant interactions between cultivar and rootstock with respect to the yield, the pruning weight, Ravaz index, $\mathrm{pH}$ and yeast assimilable nitrogen when grafting 'Chardonnay', 'Shiraz' and 'Cabernet Sauvignon' on seven rootstocks in a same location. In recent years, studies are also focusing on rootstocks that delay ripening, as climate change is advancing phenology and this may cause unbalanced grapes and compromise wine quality in warmer regions (van Leeuwen and Darriet, 2016; García de CortázarAtarui et al., 2017; Delrot et al., 2020). The increased frequency and duration of droughts is also encouraging the studies on rootstocks tolerant to drought (Gullo et al., 2018; Sabir and Sahin, 2018).
The cultivation of grapevines in Asturias (Northwestern Spain) dates back to the $8^{\text {th }}$ century, but in the $20^{\text {th }}$ century the cultivated surface was drastically reduced because of the migration of the rural population to the cities and the boom in coalmining activities (Moreno-Sanz et al., 2011). Nowadays, this crop is seeing its recovery, attested by the recent recognition of the Designation of Origin Cangas (https://ec.europa.eu/). The old vineyards were mostly planted before 1940, are disposed on steep slopes and have a great varietal diversity and a smallholder character, with areas of less than one hectare (Moreno-Sanz et al., 2011). New plantations are established on terraces. Wines are characterized by their freshness, acidity and aroma, as a result of the slow ripening of the grapes because of the climatic conditions, as the latest ripening cultivars are harvested in mid-October (Loureiro et al., 2016).

The most frequently planted cultivars are 'Albarín Negro', 'Carrasquín', 'Verdejo Negro' and 'Albarín Blanco'. 'Verdejo Negro' is a pre-phylloxeric cultivar widely disseminated in the northwest of the Iberian Peninsula because of its early ripening but, due to its low tolerance to botrytis and low polyphenol content, it has not achieved a greater extension throughout the history. This cultivar was first cited in 1531 in Portugal with the name of 'Bastardo' (Fernandes, 2012), although it is native to the Jura region of France, where it is known as 'Trousseau Noir' (Cunha et al., 2010; Robinson et al., 2012). It has long been planted in Asturias with the denomination of 'Verdejo Negro'/ 'Verdejo Tinto'/'Verdello Tinto', and in other regions of Spain as 'Bastardo', 'Merenzao', 'María Ordoña', 'Carnaz' or 'Roibal'. It is also cultivated with the name of 'Bastardo' in Portugal and Cyprus. The area under cultivation with this cultivar was 188 ha in South Africa in the year $2000 ; 1100$ ha in Portugal, 150 ha in France and 250 ha in Australia in 2007; and 112 ha in Spain in the year 2009 (Cabello et al., 2012; www.vivc.de). Monovarietal wines begin to be produced in Asturias, and the clonal selection of this cultivar has recently been performed (Loureiro et al., 2017). 'Verdejo Negro' wines present intense flower scents, a high $\mathrm{pH}$ and alcoholic content, and low concentrations of acids and anthocyanins (Fong et al., 1971; Brites and Pedroso, 2000; Sousa et al., 2008; Lourenço, 2013; Costa et al., 2014; Shellie et al., 2014).

The changing wine market is demanding new styles of wines, and local cultivars are acquiring importance as providers of different tastes. This gave rise to a boom in the cultivation of local cultivars worldwide, being peremptory the study of their characteristics and the most optimal cultivation techniques for quality. The lengthy abandonment suffered by the Asturian vineyards has led to a complete lack of 
knowledge about the enological potential and the most suitable cultivation techniques for the cultivars grown in the region. For these reasons, the agronomical and enological characteristics of 'Verdejo Negro' grafted on three rootstocks were evaluated with the aim of advising the grape growers about the best rootstock for this cultivar and site.

\section{MATERIAL AND METHODS}

\section{Plot characterization and experimental design}

The trial was performed in a vineyard on a slate soil sited on terraces in the heart of the wine growing region in Cangas del Narcea (Asturias, Spain, 43 $8^{\prime} 45.79^{\prime}$ ' N, 6 32 ' $\left.16.00^{\prime \prime} \mathrm{W}\right)$. The soil is typical of this region, with a sandy-loam texture, a medium content of organic matter, an acidic $\mathrm{pH}$ (6.06), and low potassium levels (Table I). The study was conducted in vines established in 2005 in a completely randomized design with three repetitions of 10 vines for each rootstock. The rootstocks assessed for their adaptability to 'Verdejo Negro' were '196-17 C' ['1203 C' ('Mourvèdre' × $V$. rupestris $) \times V$. riparia)], '101-14 $\mathrm{MG}^{\prime}$ and '3309 C' $(V$. riparia $\times V$. rupestris in both cases). The terraces were $2.0 \mathrm{~m}$ wide and the within-row spacing was 0.80 $\mathrm{m}$. The plants were trained in a vertical shoot positioning system using a single Royat cordon, and pruned to four spurs with two buds each. The study was performed between the years 2010 and 2012 .

\section{Table I}

Results of the soil analysis of the vineyard

Resultados da análise do solo da vinha

\begin{tabular}{|c|c|}
\hline Texture & $\begin{array}{c}\text { Sandy-loam } \\
5 \% \text { clay, } 64 \% \text { sand, } \\
31 \% \text { silt }\end{array}$ \\
\hline $\mathrm{pH}\left(\mathrm{H}_{2} \mathrm{O}\right)$ & 6.06 \\
\hline Organic matter $(\%)$ & 1.98 \\
\hline Total Nitrogen (\%) & 0.19 \\
\hline Phosphorous (mg/Kg $\left.\mathrm{P}_{2} \mathrm{O}_{5}\right)^{1}$ & 23.9 \\
\hline Potassium $\left(\mathrm{mg} / \mathrm{g} \mathrm{K}_{2} \mathrm{O}\right)^{2}$ & $<0.15$ \\
\hline Magnesium (mg/g MgO) ${ }^{2}$ & 0.381 \\
\hline Cation exchange capacity (meq $\mathrm{Na} / 100 \mathrm{~g}$ ) & 14.2 \\
\hline
\end{tabular}

${ }^{1}$ Olsen method; ${ }^{2}$ Extractable in ammonium acetate.

\section{Agronomical evaluation}

Dates of budburst (stage C), flowering (I) and veraison $(\mathrm{M})$ were recorded for each vine following the Baggiolini phenological scale (Baggiolini, 1952).
The date of full stage was considered to be when $50 \%$ of the organs were in that stage. Dates are expressed as number of days passed from $1^{\text {st }}$ of March.

Yield was measured as the weight of the total bunches and the vegetative development by the pruning weight. The productive to vegetative balance was evaluated through the Ravaz index, defined as the ratio yield/pruning wood weight (Smart and Robinson, 1991).

\section{Berry composition, wine making and analysis}

Berry weight, total soluble solids ( $\left.{ }^{\circ} \mathrm{Brix}\right), \mathrm{pH}$, total acidity, organic acids (malic and shikimic acids) and total polyphenol index (TPI) were determined from a sample of 500 berries of 'Verdejo Negro' grafted on each rootstock at harvest.

Bunches were picked manually, destemmed and slightly crushed with a motorized grape crusher, and a sample of must was taken. Alcoholic fermentation was conducted with commercial yeast (Saccharomyces cerevisiae, Viniferm CR, $30 \mathrm{~g} / \mathrm{hL}$ ) between $22-25{ }^{\circ} \mathrm{C}$ in $15 \mathrm{~L}$ stainless steel-tanks. Grape pomace was punched down manually every day. When the alcoholic fermentation was finished, wine was racked off and inoculated with lactic acid bacteria (Oenococcus oeni, Vitilactic $\mathrm{H}+, 0.5 \mathrm{~g} / \mathrm{hL}$ ). Once the malolactic fermentation was completed, wines were corrected to $30 \mathrm{mg} / \mathrm{L}$ of free sulfur dioxide, filtered by Polygard $(0.3 \mu \mathrm{m}$, Merck Millipore) and bottled.

The wines were analyzed and sensorially evaluated two months after bottling. The following data were recorded:

- Must: total soluble solids ( $\left.{ }^{\circ} \mathrm{Brix}\right), \mathrm{pH}$, total acidity and organic acids (malic and shikimic acids).

- Wine: alcoholic degree, $\mathrm{pH}$, total acidity, volatile acidity, acids (lactic and shikimic acids), glycerin, major volatile compounds (ethyl acetate, methanol, propanol, isobutanol, amyl alcohols, ethyl lactate, 2phenylethanol), tonality $\left(\mathrm{A}_{420} / \mathrm{A}_{520}\right)$ and total phenolic index (TPI; $\mathrm{A}_{280}$ ).

- Sensory analysis of wines: it was performed by six experienced tasters, in standardized wine tasting glasses (UNE-87022:1992). Visual, nose and taste parameters, and global evaluation were scored following the OIV sheet for still wines (www.oiv.int, Figure 1). The median of the scores of all the tasters was calculated for each attribute.

Total soluble solids were measured by electronic densimetry; probable alcoholic degree by near infrared spectroscopy; $\mathrm{pH}$, total and volatile acidities according to the OIV international methods (www.oiv.int); tonality $\left(\mathrm{A}_{420} / \mathrm{A}_{520}\right)$ and TPI $\left(\mathrm{A}_{280}\right)$ by UV-VIS spectrophotometry; glycerin and organic acids according to Picinelli et al. (2000); volatile 
compounds following that reported by Suárez et al. (2005).

The Weaver maturity index (Hidalgo, 2003), defined as the total soluble solids ( ${ }^{\circ}$ Brix)/total acidity ( $\mathrm{g}$ tartaric acid/100 $\mathrm{mL}$ ) ratio was calculated for berry and must.

\section{Statistical analysis}

A one-way analysis of variance (ANOVA) and the Duncan test (or Games-Howell test in the case of unequal variances) of the phenological data were performed with SPSS v. 12.0 software for each year. Agronomical and enological data were evaluated by ANOVA with the Design-Expert 7.0.0 statistical package, taking the rootstock as the fixed factor and the year as random factor. A Principal Component Analysis (PCA) was performed on the wine data. The data matrix consisted of nine objects (wines) and 12 variables (the analyzed parameters).

\begin{tabular}{|c|c|c|c|c|c|c|c|}
\hline \multicolumn{2}{|r|}{ STILL WINES } & 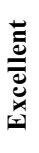 & 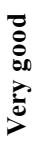 & 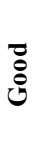 & 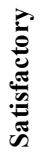 & 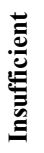 & Additional obs ervations \\
\hline \multirow{2}{*}{ VISUAL } & Limpidity & 5 & 4 & 3 & 2 & 1 & \\
\hline & Color & 10 & 8 & 6 & 4 & 2 & \\
\hline \multirow{3}{*}{ NOSE } & Intensity & 8 & 7 & 6 & 4 & 2 & \\
\hline & Cleanliness & 6 & 5 & 4 & 3 & 2 & \\
\hline & Quality & 16 & 14 & 12 & 10 & 8 & \\
\hline \multirow{4}{*}{ TASTE } & Intensity & 8 & 7 & 6 & 4 & 2 & \\
\hline & Cleanliness & 6 & 5 & 4 & 3 & 2 & \\
\hline & Quality & 22 & 19 & 16 & 13 & 10 & \\
\hline & Persistency & 8 & 7 & 6 & 5 & 4 & \\
\hline & O VERALL JUDGEMENT & 11 & 10 & 9 & 8 & 7 & \\
\hline \multicolumn{7}{|c|}{ TOTAL } & \\
\hline
\end{tabular}

Figure 1. OIV sheet for still wines.

Ficha de prova de vinhos tranquilos.

\section{RESULTS AND DISCUSSION}

The reconstitution of the Asturian vineyards after the phylloxera was performed with 'Rupestris de Lot' and '3309 C' rootstocks, selected as being the best adapted to the local cultivars (Naredo, 1914). The grafting on 'Rupestris de Lot' is at present in decline worldwide because the high vigor it confers on the scion can induce poor berry set in some cultivars; in addition, its long vegetative cycle retards the maturation (Chomé et al., 2006). The new plantations established in recent years in Asturias are grafted according to the rootstock available in the nursery. As no studies have been carried out to determine the most suitable rootstock to achieve optimal quality for 'Verdejo Negro' in this region, the present research into the effect of the grafting on different rootstocks upon the agronomical and enological characteristics of this cultivar was undertaken.

Three rootstocks were selected for the study, '101-14 MG' and '3309 C', both with the same parent species, but the first recommended for quality and the second for production, and ' $196-17$ C', which is suited to acid soils (Galet, 1998), such as those of this part of
Asturias. Concerning the climatological conditions during the study, no data could be collected in 2010 due to technical problems in the weather station. Climatic conditions in 2011 and 2012 were very different; 2011 was quite warmer and dryer in the vegetative period than 2012 (Table II), with the consequent effect on phenology. In fact, the low temperatures $\left(<10^{\circ} \mathrm{C}\right)$ recorded in April 2012 retarded the budburst by more than three weeks that year, and the flowering was also delayed (Figure 2, Table III).

Rootstocks are reported in the literature that influence phenology; late ripening rootstocks being able to delay phenology by as much as 2-6 days depending on the vintage, compared to early ripening rootstocks (van Leeuwen and Destrac-Irvine, 2017). In the present study, the only significant effect of rootstock on phenology was an earlier veraison date (about 3-4 days) for 'Verdejo Negro' grafted on '101-14 MG' in the last two years of the trial (Table III). This behavior was also recorded by Loureiro et al. (2016) when evaluating the grafting of the Asturian cultivar 'Albarín Negro' on five rootstocks, including those studied in this work. The '101-14 MG' rootstock is generally considered as good for quality (Ollat et al., 
2003), although Renouf et al. (2010) scored it with a low quality index in a study performed over a wide area in Bordeaux. The differential effect of rootstocks on phenology has been recorded in other studies. $\mathrm{Gu}$ et al. (2005) observed a hastening of the budburst date in 'Gewürztraminer' with '3309 C' and '420 A' in a study with six rootstocks. Jogaiah et al. (2013) stated that 'Dogridge' retarded the budburst of 'Thompson Seedless' in a comparative study with five rootstocks.

\section{Table II}

Climatic index, temperatures and rainfall data

Índices climáticos, dados de temperatura e de precipitação

\begin{tabular}{|c|c|c|}
\hline & 2011 & 2012 \\
\hline Active Thermal Integral $\left({ }^{\circ} \mathrm{C}\right)^{1}$ & 3205.8 & 2638.1 \\
\hline Growing degree days $\left({ }^{\circ} \mathrm{C}, \text { Winkler \& Amerine }\right)^{1}$ & 1325.8 & 1038.1 \\
\hline Average temperature $\left({ }^{\circ} \mathrm{C}\right)^{1}$ & 17.1 & 15.3 \\
\hline Average of maximum temperatures $\left({ }^{\circ} \mathrm{C}\right)^{1}$ & 22.9 & 20.7 \\
\hline Average of minimum temperatures $\left({ }^{\circ} \mathrm{C}\right)^{1}$ & 11.1 & 10.0 \\
\hline Rainfall (mm) ${ }^{1}$ & 480.3 & 583.2 \\
\hline Summer rainfall $(\mathrm{mm})^{2}$ & 228.1 & 198.9 \\
\hline Rainfall of the month before harvest $(\mathrm{mm})^{3}$ & 41.2 & 61.0 \\
\hline
\end{tabular}

${ }^{1}$ Active period (from April to harvest date) $;{ }^{2}$ From June to August; ${ }^{3}$ September.
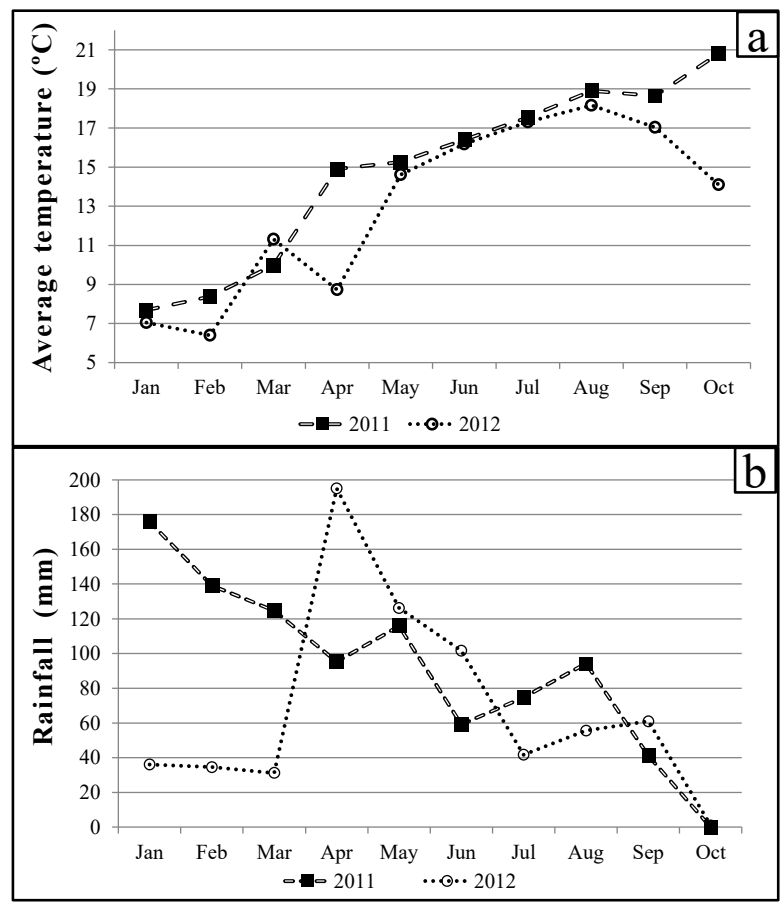

Figure 2. Average temperatures (a) and rainfall (b) between January and harvest (2011-2012).

Temperaturas médias (a) e precipitação (b) entre janeiro e a vindima (2011-2012). 
Table III

Phenological data of 'Verdejo Negro' in the tested rootstocks. Days from the $1^{\text {st }}$ of March

Dados fenológicos de 'Verdejo Negro’ nos porta-enxertos avaliados. Dias a partir de 1 de Março

\begin{tabular}{|c|c|c|c|c|}
\hline \multirow{2}{*}{ Phenological stage } & \multirow{2}{*}{ Year } & \multicolumn{3}{|c|}{ Rootstock } \\
\hline & & 196-17 C & 101-14 MG & $3309 \mathrm{C}$ \\
\hline \multirow{3}{*}{ Budburst date (Stage C) } & 2010 & $43.22^{\mathrm{a}}$ & $41.96^{\mathrm{a}}$ & $43.58^{\mathrm{a}}$ \\
\hline & 2011 & $35.00^{\mathrm{a}}$ & $35.40^{\mathrm{a}}$ & $35.60^{\mathrm{a}}$ \\
\hline & 2012 & $61.10^{\mathrm{a}, \mathrm{b}}$ & $60.62^{\mathrm{a}}$ & $62.05^{\mathrm{b}}$ \\
\hline \multirow{3}{*}{ Flowering date (Stage I) } & 2010 & $111.48^{\mathrm{a}}$ & $110.30^{\mathrm{a}}$ & $109.17^{\mathrm{a}}$ \\
\hline & 2011 & $100.13^{\mathrm{a}}$ & $102.33^{\mathrm{a}}$ & $102.70^{\mathrm{a}}$ \\
\hline & 2012 & $116.10^{\mathrm{b}}$ & $115.08^{\mathrm{a}}$ & $116.14^{\mathrm{b}}$ \\
\hline \multirow{3}{*}{ Veraison date (Stage $\mathrm{M}$ ) } & 2010 & $179.00^{\mathrm{a}}$ & $179.00^{\mathrm{a}}$ & $176.43^{\mathrm{a}}$ \\
\hline & 2011 & $183.80^{\mathrm{b}}$ & $179.00^{\mathrm{a}}$ & $182.33^{\mathrm{b}}$ \\
\hline & 2012 & $184.66^{\mathrm{b}}$ & $179.96^{\mathrm{a}}$ & $183.45^{\mathrm{b}}$ \\
\hline \multirow{3}{*}{ Flowering- Veraison period } & 2010 & $67.90^{\mathrm{a}}$ & $68.08^{\mathrm{a}}$ & $64.00^{\mathrm{a}}$ \\
\hline & 2011 & $83.14^{\mathrm{b}}$ & $77.88^{\mathrm{a}}$ & $79.60^{\mathrm{a}}$ \\
\hline & 2012 & $68.55^{\mathrm{b}}$ & $64.88^{\mathrm{a}}$ & $67.35^{\mathrm{a}, \mathrm{b}}$ \\
\hline \multirow{3}{*}{ Budburst - Harvest period } & 2010 & $175.78^{\mathrm{a}}$ & $177.04^{\mathrm{a}}$ & $175.42^{\mathrm{a}}$ \\
\hline & 2011 & $185.00^{\mathrm{a}}$ & $184.60^{\mathrm{a}}$ & $184.40^{\mathrm{a}}$ \\
\hline & 2012 & $156.90^{\mathrm{a}, \mathrm{b}}$ & $157.38^{\mathrm{b}}$ & $155.95^{\mathrm{a}}$ \\
\hline
\end{tabular}

Average values in a same row, with the same letter as super index did not show significant differences between them. $\mathrm{p}<0.05$.

Because of the low grape yield observed during this investigation, berries of the three repetitions of each rootstock were collected together at harvest, and the year was considered as repetition for statistical purposes. Harvest dates $\left(5^{\text {th }}\right.$ October in $2010,6^{\text {th }}$ October in 2011 and $4^{\text {th }}$ October in 2012) were determined through periodical controls of ${ }^{\circ} \mathrm{Brix}, \mathrm{pH}$ and titratable acidity. Although '101-14 MG' and '3309 C' rootstocks are both $V$. riparia $\mathrm{x} V$. rupestris crossings, the first has a predominance of $V$. riparia and promotes an earlier ripening and weaker vigor as compared to the second, which shows a predominance of the $V$. rupestris characteristics (Koblet et al., 1994; Galet, 1998; Reynier, 2005). Despite the earlier veraison of '101-14 MG' recorded, no significant differences in ${ }^{\circ}$ Brix degree, acid content (titratable acidity, malic and shikimic acids) or TPI in berries were found between the rootstocks at harvest. Only that of the Weaver maturity index (Hidalgo, 2003), used as a ripening index, was significant, with '101-14 MG' presenting a higher value in the berry than the other two rootstocks for all the years of the trial (Table IV). Brighenti et al. (2012) noticed a higher $\mathrm{pH}$ and berry weight and lower anthocyanin content in '101-14 MG' with respect to ' $3309 \mathrm{C}$ ' in a study performed with
'Cabernet Sauvignon' over two years. In another study of 'Cabernet Sauvignon' on seven rootstocks, '101-14 MG' presented the highest $\mathrm{pH}$ and a low titratable acidity in berry (Jogaiah et al., 2015). 'Verdejo Negro' grafted on '196-17 C' presented a slightly higher titratable acidity in berries; this is important on account of the low acidity of this cultivar. Da Mota et al. (2009) did not report significant differences in berry chemical parameters between '196-17 C' and '101-14 MG' for the 'Niágara Rosada' and 'Folha-de-Figo' cultivars. 'Albarín Negro' grafted on '196-17 C' presented similar values to those found when it was grafted on '101-14 MG' and '3309 C', in terms of $\mathrm{pH}$, titratable acidity and malic acid in berry (Loureiro et al., 2016).

Even though the difference was not significant, 'Verdejo Negro' grafted on '3309 C' produced a 60\% higher berry yield and a $21 \%$ higher pruning weight than '101-14 MG'. This lack of significant differences for yield can be explained by the high variability observed between years, since in 2012 a drastic reduction in yield was recorded for all the rootstocks (Table IV). Significant results indicating lower pruning weight and/or yield for '101-14 MG' in comparison with ' $3309 \mathrm{C}$ ' were observed in trials with the 'Syrah' (Agut et al., 2005), the 'Fernão 
Pires' (Andrade et al., 2005), the 'Cornalin' (Spring et al., 2012) and the 'Albarín Tinto' cultivars (Loureiro et al., 2016). Contradictory results with a significantly higher berry yield of 'Pinot Noir' and
'Cabernet Sauvignon' on '101-14 MG' compared to '3309 C' were noticed by Koblet et al. (1994) and Miele and Rizzon (2017), respectively.

\section{Table IV}

Agronomical and berry oenological parameters of 'Verdejo Negro' on the different rootstocks

Parâmetros agronómicos e enológicos em bagos de 'Verdejo Negro' nos diferentes porta-enxertos

\begin{tabular}{|c|c|c|c|c|c|c|c|c|c|c|c|c|}
\hline 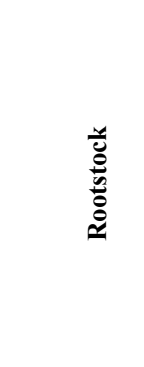 & 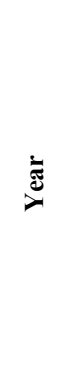 & 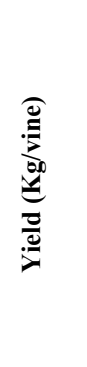 & 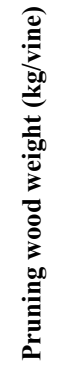 & 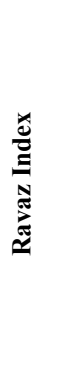 & 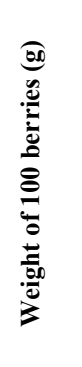 & 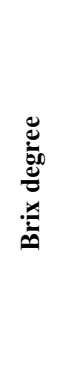 & $\frac{\pi}{2}$ & 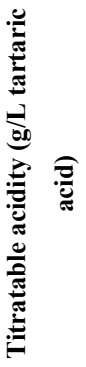 & 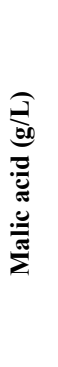 & 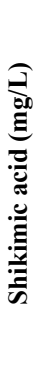 & 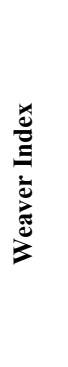 & $\bar{a}$ \\
\hline \multirow{4}{*}{ 196-17 C } & 2010 & 1.680 & 0.702 & 2.39 & 262.3 & 23.5 & 3.42 & 6.58 & 3.0 & 59 & 35.7 & 5.0 \\
\hline & 2011 & 1.060 & 1.049 & 1.01 & 269.4 & 22.4 & 3.30 & 8.23 & 3.5 & 72 & 27.2 & 6.2 \\
\hline & 2012 & 0.718 & 0,700 & 1.03 & 201.6 & 24.3 & 3.33 & 6.96 & 2.9 & 67 & 34.9 & 6.2 \\
\hline & Av. & 1.152 & 0.817 & 1.48 & 244.4 & 23.4 & 3.35 & 7.26 & 3.1 & 66 & 32.6 & 5.8 \\
\hline \multirow{4}{*}{ 101-14 MG } & 2010 & 1.060 & 0.586 & 1.81 & 257.9 & 23.5 & 3.48 & 6.23 & 3.0 & 60 & 37.7 & 5.5 \\
\hline & 2011 & 1.390 & 0.929 & 1.50 & 262.4 & 23.4 & 3.40 & 7.04 & 2.8 & 70 & 33.3 & 6.6 \\
\hline & 2012 & 0.632 & 0.549 & 1.15 & 204.8 & 24.5 & 3.41 & 5.73 & 2.4 & 73 & 42.7 & 7.8 \\
\hline & Av. & 1.027 & 0.688 & 1.49 & 241.7 & 23.8 & 3.43 & 6.33 & 2.7 & 68 & 37.9 & 6.6 \\
\hline \multirow{4}{*}{$3309 \mathrm{C}$} & 2010 & 1.960 & 0.846 & 2.32 & 254.7 & 23.7 & 3.47 & 6.78 & 3.6 & 64 & 34.9 & 9.8 \\
\hline & 2011 & 1.970 & 1.063 & 1.85 & 243.5 & 22.6 & 3.38 & 7.34 & 3.3 & 72 & 30.7 & 6.6 \\
\hline & 2012 & 1.011 & 0.600 & 1.69 & 188.5 & 23.3 & 3.32 & 6.02 & 2.7 & 67 & 38.8 & 7.4 \\
\hline & Av. & 1.647 & 0.836 & 1.95 & 228.9 & 23.2 & 3.39 & 6.71 & 3.2 & 68 & 34.8 & 7.9 \\
\hline Rootstock & & ns & $\mathrm{ns}$ & ns & ns & $\mathrm{ns}$ & ns & ns & ns & $\mathrm{ns}$ & $*$ & ns \\
\hline Year & & $*$ & $* *$ & $*$ & $* * *$ & $\mathrm{~ns}$ & $*$ & $*$ & ns & $*$ & $* *$ & $\mathrm{~ns}$ \\
\hline
\end{tabular}

TPI: total polyphenol index; Av: average; ns: not significant; $* \mathrm{p}<0.05 ; * * \mathrm{p}<0.01 ; * * * \mathrm{p}<0.001$.

Brighenti et al. (2012) and Yuste et al. (2017) did not find differences between the two rootstocks in terms of grape yield and pruning weight with 'Cabernet Sauvignon' and 'Sauvignon Blanc' cultivars, respectively. In this last study, a significantly lower berry yield was observed for '196-17 C' compared with '3309 C', and a lower pruning weight when compared with '101-14 MG'. Da Mota et al. (2009) also recorded that ' $196-17$ C' produced half the pruning weight that was seen for '101-14 MG' with the 'Niágara Rosada' and 'Folha-de-Figo' cultivars, although the difference was only significant for the first cultivar, and no differences in yield were reported. The grafting on ' $196-17$ C' of the Asturian cultivar 'Albarín Negro' produced an intermediate yield between '101-14 MG' and '3309 C' (Loureiro et al., 2016).

The musts did not present important differences among them. Only a year effect in $\mathrm{pH}$ and malic acid content could be observed (Table V).

Spring et al. (2012) noticed a higher total acidity and lower pH in musts of 'Cornalin' on '3309 C' compared to '101-14 MG'; however, no differences between the musts from these two rootstocks were found with the 'Pinot Noir' cv. (Spring et al., 2016). Loureiro et al. (2016) obtained significant differences in Brix degree, total acidity, $\mathrm{pH}$, malic acid and Weaver index in musts of the 'Albarín Negro' cv. 
grafted on five rootstocks, including the three studied in this work.

The rootstocks did not significantly influence the wine composition, except for the volatile acidity content, which was higher in those from the '3309 C' for all experimental seasons (Table VI). On the contrary, Loureiro et al. (2016) observed differences ascribed to the rootstock in glycerin, TPI, propanol and isobutanol among the wines of 'Albarín Negro'. Spring et al. (2012) recorded a lower $\mathrm{pH}$ and higher tartaric acid in wines from 'Cornalin' on '3309 C' compared to those of '101-14 MG', but Spring et al. (2016) did not observe significant differences between the wines of 'Pinot Noir' grafted on these two rootstocks. The year affected all the analyzed parameters in wine except alcoholic degree, glycerin content, tonality and TPI (Table VI).

Table V

Enological parameters of 'Verdejo Negro' musts for the different rootstocks

Parâmetros enológicos de mostos de 'Verdejo Negro' nos diferentes porta-enxertos

\begin{tabular}{|c|c|c|c|c|c|c|c|c|}
\hline 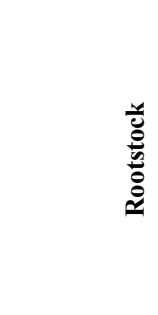 & 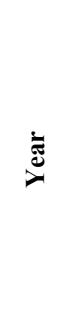 & 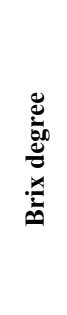 & 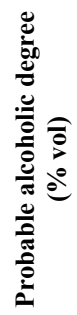 & 플 & 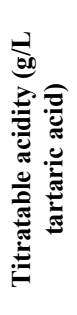 & 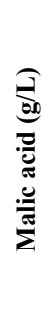 & 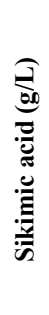 & 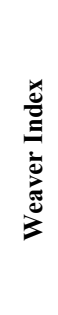 \\
\hline \multirow{4}{*}{ 196-17 C } & 2010 & 23.2 & 13.59 & 3.37 & 6.22 & 3.2 & 59 & 37.3 \\
\hline & 2011 & 22.2 & 12.90 & 3.30 & 7.48 & 2.9 & 63 & 29.7 \\
\hline & 2012 & 23.9 & 14.08 & 3.25 & 7.52 & 2.8 & 64 & 31.8 \\
\hline & Av. & 23.1 & 13.52 & 3.31 & 7.07 & 3.0 & 62 & 32.9 \\
\hline \multirow{4}{*}{ 101-14 MG } & 2010 & 23.8 & 14.01 & 3.39 & 6.53 & 3.2 & 63 & 36.4 \\
\hline & 2011 & 22.6 & 13.17 & 3.31 & 6.98 & 2.5 & 59 & 32.4 \\
\hline & 2012 & 24.3 & 14.35 & 3.30 & 5.99 & 2.2 & 66 & 40.5 \\
\hline & Av. & 23.6 & 13.84 & 3.33 & 6.50 & 2.6 & 63 & 36.4 \\
\hline \multirow{4}{*}{$3309 \mathrm{C}$} & 2010 & 23.8 & 14.01 & 3.40 & 6.41 & 3.1 & 61 & 37.1 \\
\hline & 2011 & 22.5 & 13.11 & 3.28 & 7.28 & 2.9 & 59 & 30.9 \\
\hline & 2012 & 22.6 & 13.17 & 3.22 & 6.21 & 2.2 & 56 & 36.3 \\
\hline & Av. & 23.0 & 13.43 & 3.30 & 6.63 & 2.7 & 59 & 34.8 \\
\hline Rootstock & & ns & ns & ns & ns & ns & ns & $\mathrm{ns}$ \\
\hline Year & & ns & ns & $* *$ & ns & $*$ & ns & $\mathrm{ns}$ \\
\hline
\end{tabular}

This effect can be seen in the projection on the plane of the two principal components obtained through a PCA performed to visualize possible relationships between the three rootstocks, the chemical variables (alcoholic degree, $\mathrm{pH}$, volatile acidity, lactic acid, shikimic acid, glycerin, ethyl acetate, isobutanol, amyl alcohols, 2-phenylethanol, tonality, TPI) and the years of study. The effect of the year was not very obvious in 2010. The wines of the 2011 harvest were characterized on the basis of their lower 2phenylethanol and amyl alcohols concentrations, higher volatile acidity and isobutanol contents. On the contrary, the wines of the 2012 harvest were closely grouped on the basis of their higher content of 2phenylethanol and amyl alcohols, and lower concentrations of isobutanol and lactic acid (Figure $3)$. The significant effect of year in many of the agronomical and enological parameters analyzed in this study may be explained because the plants were young and, as Neal et al. (2016) suggested, based on a long-term study of 'Sauvignon Blanc' on five rootstocks, the influence of season is more pronounced in young plants than in mature ones. 


\section{Table VI}

Enological parameters of 'Verdejo Negro' wines (two months in bottle)

Parâmetros enológicos de vinhos de 'Verdejo Negro' (dois meses em garrafa)

\begin{tabular}{|c|c|c|c|c|c|c|c|c|c|c|c|c|c|c|c|c|c|}
\hline 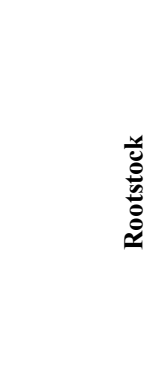 & 离 & 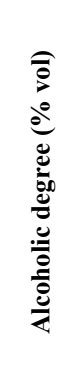 & 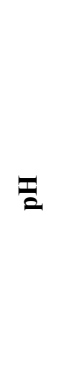 & 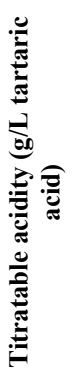 & 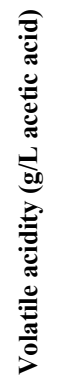 & 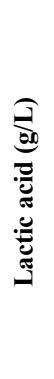 & 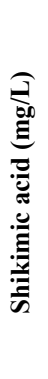 & 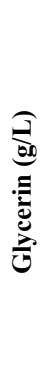 & 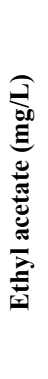 & 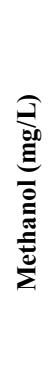 & 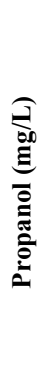 & 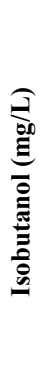 & 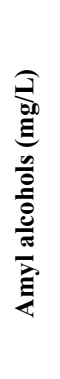 & 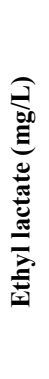 & 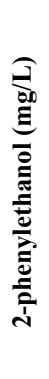 & 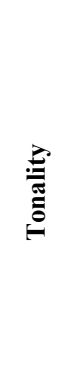 & $\overline{\mathrm{B}}$ \\
\hline \multirow{4}{*}{$196-17 \mathrm{C}$} & 2010 & 13.48 & 3.85 & 3.96 & 0.36 & 2.0 & 72 & 8.4 & 55 & 142 & 26 & 78 & 357 & 59 & 49 & 0.819 & 21.0 \\
\hline & 2011 & 12.56 & 3.89 & 3.84 & 0.47 & 2.3 & 86 & 8.3 & 53 & 166 & 36 & 89 & 298 & 60 & 36 & 0.699 & 24.3 \\
\hline & 2012 & 13.45 & 3.79 & 4.46 & 0.41 & 1.7 & 87 & 8.4 & 40 & 135 & 25 & 75 & 423 & 31 & 65 & 0.790 & 23.1 \\
\hline & Av. & 13.16 & 3.84 & 4.09 & 0.41 & 2.0 & 81 & 8.4 & 49 & 147 & 29 & 81 & 360 & 50 & 50 & 0.769 & 22.8 \\
\hline \multirow{4}{*}{ 101-14 MG } & 2010 & 13.66 & 3.99 & 3.75 & 0.35 & 2.1 & 78 & 9.1 & 52 & 148 & 24 & 77 & 410 & 54 & 68 & 0.708 & 25.8 \\
\hline & 2011 & 12.66 & 3.99 & 3.45 & 0.46 & 2.3 & 91 & 8.2 & 50 & 176 & 29 & 86 & 316 & 52 & 42 & 0.834 & 24.3 \\
\hline & 2012 & 13.88 & 3.77 & 4.38 & 0.41 & 1.4 & 82 & 8.6 & 41 & 122 & 24 & 66 & 433 & 25 & 80 & 0.769 & 23.9 \\
\hline & Av. & 13.40 & 3.92 & 3.86 & 0.41 & 1.9 & 84 & 8.6 & 48 & 149 & 26 & 76 & 386 & 44 & 63 & 0.770 & 24.7 \\
\hline \multirow{4}{*}{$3309 \mathrm{C}$} & 2010 & 13.75 & 3.98 & 3.76 & 0.43 & 2.3 & 80 & 9.1 & 59 & 161 & 28 & 81 & 368 & 67 & 53 & 0.806 & 24.5 \\
\hline & 2011 & 12.71 & 3.96 & 3.89 & 0.51 & 2.3 & 92 & 8.3 & 49 & 172 & 32 & 89 & 342 & 55 & 46 & 0.833 & 22.0 \\
\hline & 2012 & 12.67 & 3.73 & 4.54 & 0.45 & 1.4 & 81 & 8.2 & 48 & 93 & 28 & 57 & 374 & 23 & 64 & 0.791 & 22.0 \\
\hline & Av. & 13.04 & 3.89 & 4.06 & 0.46 & 2.0 & 84 & 8.5 & 52 & 142 & 29 & 76 & 361 & 48 & 54 & 0.810 & 22.8 \\
\hline Rootstock & & ns & $\mathrm{ns}$ & ns & $* *$ & ns & ns & ns & ns & ns & ns & ns & ns & ns & $\mathrm{ns}$ & ns & ns \\
\hline Year & & ns & * & $* *$ & $* * *$ & $* *$ & $*$ & ns & $*$ & * & $*$ & * & * & $* *$ & * & ns & ns \\
\hline
\end{tabular}

TPI: Total polyphenol index; Av: average; ns: not significant; * $\mathrm{p}<0.05 ;{ }^{* *} \mathrm{p}<0.01 ;{ }^{* * *} \mathrm{p}<0.001$.

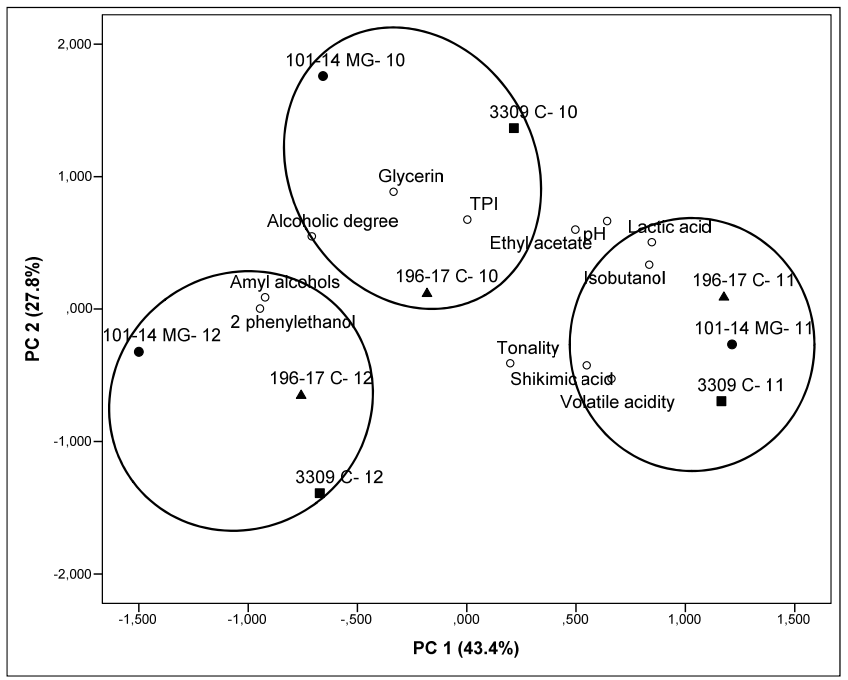

Figure 3. 'Verdejo Negro' wines after two months in bottle (years 2010-2012). Projection on the plane of the two first principal components. Vinhos de 'Verdejo Negro' depois de dois meses em garrafa (anos 2010-2012). Projeção no plano das duas primeiras componentes principais. 
The sensory analysis of the wines is required for a complete understanding of the influence of rootstocks on their quality. All the wines were in general poor in color, with low intensity and quality for nose and taste. In fact, 'Merenzao' (a synonym for 'Verdejo Negro') produced the least appreciated wines in a study with five red cultivars from Northwestern Spain
(Vilanova et al., 2012). The sensorial analysis showed a slightly better score for the wines elaborated from '101-14 MG' for nose parameters and for taste parameters in the case of the wines from the '196-17 C' rootstock, although the overall judgment was very similar for all the wines tasted (Figures 4 and 5).

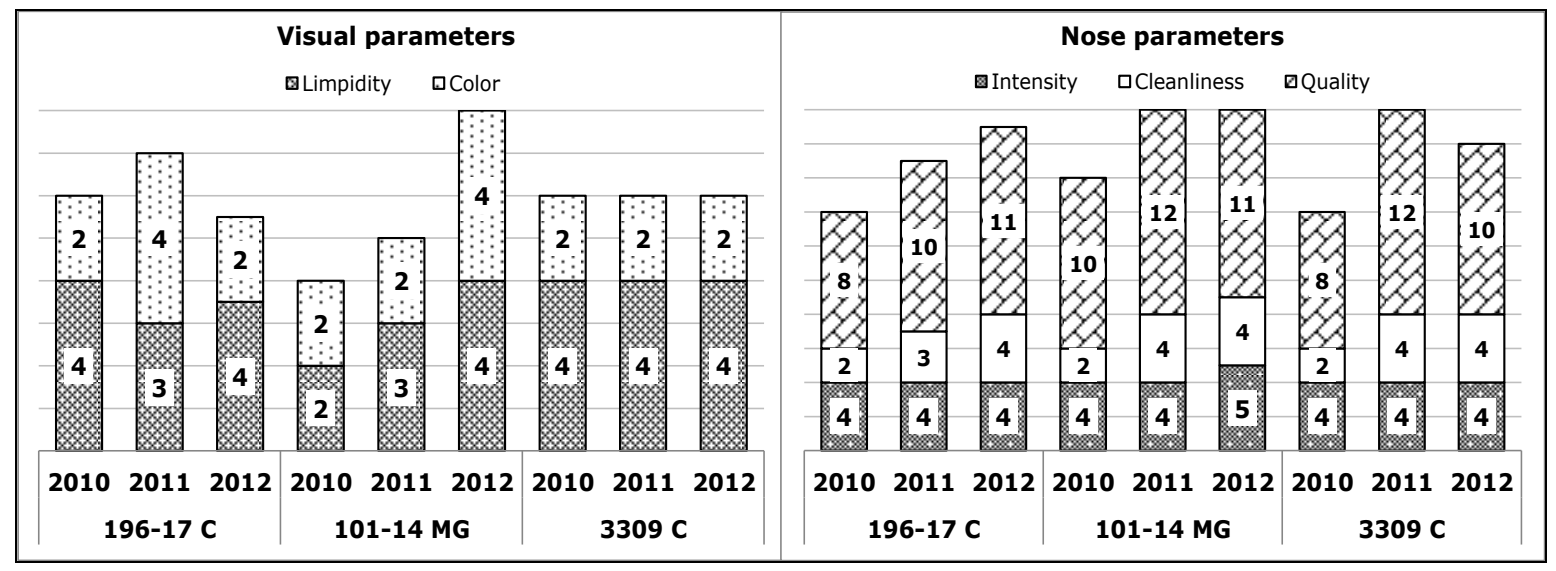

Figure 4. Visual and odor parameters of 'Verdejo Negro' wines. Median values of all the scores.

Parâmetros visuais e olfativos dos vinhos de 'Verdejo Negro'. Valores medianos de todas as pontuações.

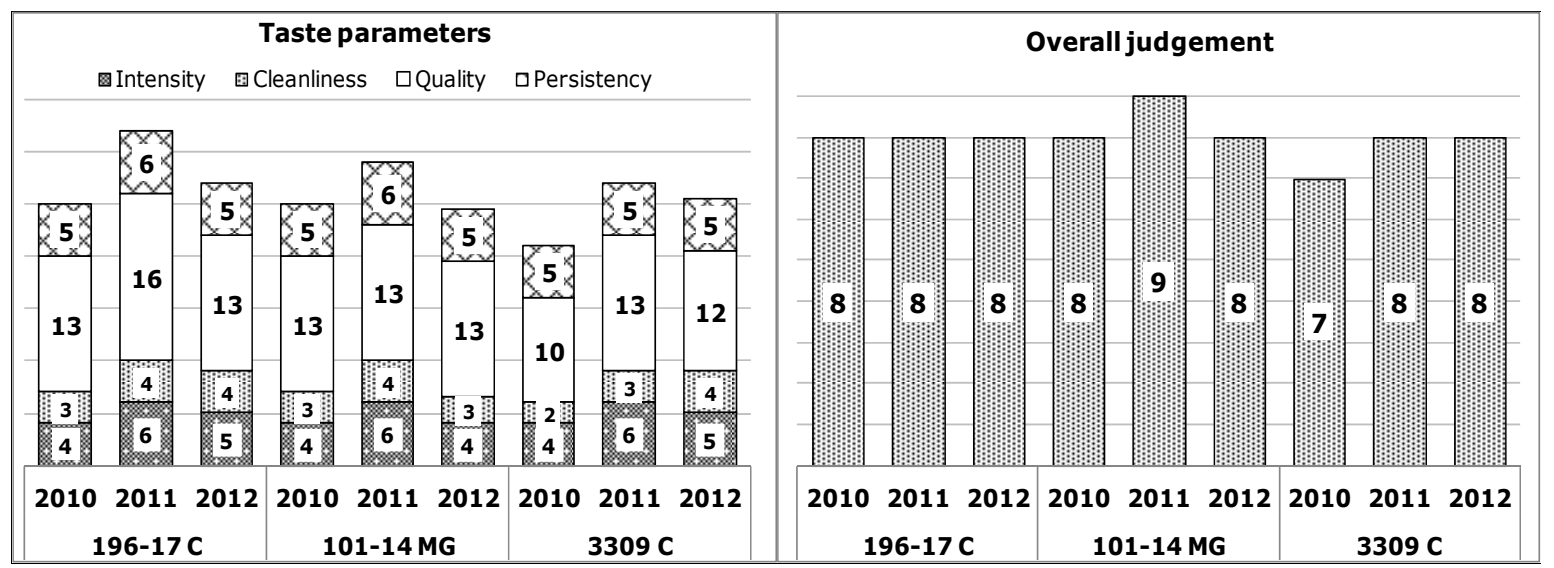

Figure 5. Taste parameters and overall judgment of 'Verdejo Negro' wines. Median values of all the scores.

Parâmetros de sabor e avaliação global dos vinhos de 'Verdejo Negro'. Valores medianos de todas as pontuações.

Spring et al. (2012) did not find significant differences in sensorial analysis between the wines of 'Cornalin' on six rootstocks, with '101-14 MG' and '3309 C' included among then. In another study with the 'Albarín Negro' cultivar on five rootstocks, the grafting on '196-17 C' produced the most highly valued wines (Loureiro et al., 2016). In a study of
'Cabernet Sauvignon' grafted on seven rootstocks, Sivilotti et al. (2007) stated that rootstock influence was more pronounced in the productive parameters that in those related to berry quality, and that the year had more effect than rootstock on the flavor of wines. In this case, the wines of the 2010 season had the worst evaluation in nose parameters, while those of 
2011 were the most highly valued in taste parameters (Figures 4 and 5).

In the present context of climatic change, the increasing temperatures are beginning to induce an advance in maturity dates (Ramos et al., 2018), with the associated rise in sugar contents and $\mathrm{pH}$, the decrease in acids and aromas, and a decoupling between the sugars and anthocyanin synthesis, leading to unbalanced wines (Jones et al., 2005). Severe water stress can also affect yield, damage leaves and stop grape ripening (van Leeuwen and Darriet, 2016). One of the measures to confront these problems is the election of rootstocks tolerant to drought and capable of retarding maturation. Taking into account that the grapevine is a long-term crop, and despite the slightly higher aromatic quality of the 'Verdejo Negro' wines obtained with the '101-14 MG' rootstock, its cataloging as low tolerant to drought (Zhang et al., 2016) and advancing ripening suggests that it may yield unbalanced wines in the future, given the high content in sugars and low acidity of the 'Verdejo Negro' cultivar. Concerning '3309 C', it has the advantage of its higher berry yield but it is also catalogued as sensitive to drought, so the plants may suffer in the future from the effects of water deficit. '196-17 C' wines are well valued in taste, and this rootstock also has the advantage of its tolerance to drought (Zhang et al., 2016), which is an important point to consider for the establishment of new plantations

\section{CONCLUSIONS}

The effect of three rootstocks on the agronomical and enological parameters of the 'Verdejo Negro' cv. was assessed in this study. The grafting on '101-14 MG' advanced the ripening, and differences ascribed to the rootstock in the Weaver maturation index and volatile acidity were noticed. The effect of year was more pronounced than that of the rootstock. The sensory analysis of the wines did not show sufficiently clear differences to allow the selection of any one of the rootstocks. Considering the high sugar content and low acidity of 'Verdejo Negro', and that earlier phenological events are predicted as a consequence of the climatic change, a rootstock that advances ripening such as '101-14 MG' will not be advisable for obtaining balanced wines of the 'Verdejo Negro' cultivar.

\section{ACKNOWLEDGEMENTS}

The authors wish to thank José Calvo for the free cession of the plot where the trial was performed; Raquel García and the students and teachers of
FUCOMI (Fundación Comarcas Mineras) viticulture workshops and the SERIDA workers who collaborated in the maintenance of the vineyard and the enological analysis; Dr. Rodríguez-Madrera for helping with the statistical analysis and Dr. PicinelliLobo for her critical review of the manuscript.

\section{REFERENCES}

Agut C., Rodríguez-Lovelle B., Fabre F., 2005. Incidence du portegreffe sur le comportement du cépage Syrah. Proc. XIV $V^{\text {th }}$ International GESCO Viticulture Congress. Geisenheim, Germany, 2, 148-154.

Alves F., Eldmann M., Costa J., Costa P., Costa P.L., Symington C., 2012. Effects of rootstock and environment on the behaviour of autochthone grapevine varieties in the Douro region. Proc. I $X^{\text {th }}$ International Terroirs Congress. Dijon/Reims, France. Available at: $\quad$ http://www.advid.pt/imagens/artigos/13492830176271.pdf (accessed on 14.07.2019).

Andrade A., Aires A., Almeida C., 2005. Agronomic behavior of grapevine Fernão Pires on three rootstocks, at Demarcated Region of Bairrada, Portugal. Proc. XIV International GESCO Viticulture Congress. Geisenheim, Germany, 2, 134-139.

Baggiolini M., 1952. Les stades repères dans le développement annuel de la vigne et leur utilisation pratique. Rev. romande Agric. Vitic. Arboric., 8, 4-6.

Brighenti A., Rufato L., Wurz D., Brighenti E., 2012. Effect of different rootstocks on productivity and quality of 'Cabernet Sauvignon' grapevine produced in high altitude. Acta Hortic., 931, 385-388.

Brites J., Pedroso V., 2000. Castas recomendadas na Região do Dão. 24 p. Direcção Regional de Agricultura da Beira Litoral. Centro de Estudios Vitivinícolas do Dão.

Cabello F., Muñoz-Organero G., Saiz R., Gaforio L., Cabezas J. A., de Andrés M. T., 2012. Situación del patrimonio varietal de vid en España. Bull. O.I.V., 85 (971-973), 23-47.

Chomé P.M., Sotés V., Benayas F., Cayuela M., Hernández M., Cabello F., Ortiz J., Rodríguez I., Chaves J., 2006. Variedades de vid. Registro de variedades comerciales. 303 p. Ministerio de Agricultura, Pesca y Alimentación (Ed.), Madrid.

Clingeleffer P., Morales N., Davis H., Smith H., 2019. The significance of scion $\times$ rootstock interactions. OENO One, 2, 335346.

Costa E., Cosme F., Jordão A.M., Mendes-Faia A., 2014. Anthocyanin profile and antioxidant activity from 24 grape varieties cultivated in two Portuguese wine regions. J. Int. Sci. Vigne Vin, 48, 51-62.

Cunha J., Teixeira-Santos M., Veloso M., Carneiro L., Eiras-Dias J., Fevereiro P., 2010. The Portuguese Vitis Vinifera L. germplasm: genetic relations between wild and cultivated vines. Ciência e Téc. Vitiv., 25, 25-37.

da Mota R.V., de Souza C.R., Favero A. C., Pinheiro Carvalho e Silva C., Lopes do Carmo E., Fonseca A.R., de Albuquerque Regina M., 2009. Produtividade e composição físico-química de bagas de cultivares de uva em distintos porta-enxertos. Pesq. agropec. bras., Brasília, 44, 576-582.

Delrot S., Grimplet J., Carbonell-Bejerano P., Schwandner A., Bert P-F., Bavaresco L., Dalla Costa L., Di Gaspero G., Duchêne E., Hausmann L., Malnoy M., Morgante M., Ollat N., Pecile M. Vezzulli S., 2020. Genetic and Genomic Approaches for 
Adaptation of Grapevine to Climate Change. In: Genomic Designing of Climate-Smart Fruit Crops. 157-270. Kole C. (Ed.) Springer, Cham.

Fernandes R., 2012. Descrição do terreno ao redor de Lamego duas léguas [1531-1532]. $1^{\mathrm{a}}$ ed (Edição crítica de Amândio Morais Barros). 126 p. Caleidoscópio - Ediçâo e Artes Gráficas, S.A.

Fong R.A., Kepner R.E., Webb A.D., 1971. Acetic-Acid-Acylated Anthocyanin Pigments in the Grape Skins of a Number of Varieties of Vitis vinifera. Am. J. Enol. Vitic., 22, 150-155.

Galet P., 1998. Précis d'Ampélographie Pratique. 256 p. $7^{\text {th }}$ edition. JF Impression (Ed.), Saint-Jean de Védas, France.

García de Cortázar-Atauri I., Duchêne E., Destrac-Irvine A., Barbeau G., de Rességuier L., Lacombe T., Parker A.K., Saurin N., van Leeuwen C., 2017. Grapevine phenology in France: from past observations to future evolutions in the context of climate change. OENO One, 51, 115-126.

$\mathrm{Gu}$ S., Read P.E., Gamet S., 2005. Performance of 'Gewurztraminer' on Six Rootstocks Under Marginal Climatic Conditions. Proc. Grapevine Rootstocks: Current Use, Research, and Application, Rootstock Symposium. Osage Beach, Missouri, 57-60.

Gullo G., Dattola A., Vonella V., Zappia R., 2018. Evaluation of water relation parameters in Vitis rootstocks with different drought tolerance and their effects on growth of a grafted cultivar. J. Plant Physiol., 226, 172-178.

Gutiérrez-Gamboa G., Gómez-Plaza E., Bautista-Ortín A.B., Garde-Cerdán T., Moreno-Simunovic Y., Martínez-Gil A.M., 2019. Rootstock effects on grape anthocyanins, skin and seed proanthocyanidins and wine color and phenolic compounds from Vitis vinifera L. Merlot grapevines. J Sci Food Agric., 99, 28462854.

Hidalgo J., 2003. Tratado de Enología. Tomo I. 752 p. MundiPrensa (Ed.), Madrid, Spain.

Jogaiah S., Kitture A.R., Sharma A.K., Sharma J., Upadhyay A.K., Somkuwar R.G., 2015. Regulation of fruit and wine quality parameters of 'Cabernet Sauvignon' grapevines (Vitis vinifera L.) by rootstocks in semiarid regions of India. Vitis, 54, 65-72.

Jogaiah S., Oulkar D.P., Banerjee K., Sharma J., Patil A.G., Maske S.R., Somkuwar R.G., 2013. Biochemically induced variations during some phenological stages in Thompson Seedless grapevines grafted on different rootstocks. S. Afr. J. Enol. Vitic., 34, 36-45.

Jones G.V., White M.A., Cooper O.R., Storchmann K., 2005. Climate change and global wine quality. Clim. Change, 73, 319343.

Koblet W., Candolfi-Vasconcelos M.C., Zweifel W., Howell G.S., 1994. Influence of leaf removal, rootstock and training system on yield and fruit composition of Pinot noir grapevines. Am. J. Enol. Vitic, 45 (2), 181-187.

Li M., Guo Z., Jia N., Yuan J., Han B., Yin Y., Sun Y., Liu C., Zhao S., 2019. Evaluation of eight rootstocks on the growth and berry quality of 'Marselan' grapevines. Sci. Hort., 248, 58-61.

Loureiro M.D., Moreno-Sanz P., García A., Fernández O., Fernández N., Suárez B., 2016. Influence of rootstock on the performance of the Albarín Negro minority grapevine cultivar. Sci. Hort.., 201, 145-152.

Loureiro M.D., Moreno-Sanz P., Suárez B., 2017. Selección clonal de cultivares de vid del Principado de Asturias. 83 pp. SERIDA (Ed.), Asturias, Spain.

Lourenço M. M., 2013. Influência das Condições Climáticas na Produção e Qualidade Vitivinícola da Sub-região de Castelo
Rodrigo entre 1992 e 2012. 129 p. Dissertação de Mestrado em Geografia Física, Departamento de Geografia da Faculdade de Letras, Universidade de Coimbra.

Marín D., García R., Eraso J., Urrestarazu J., Miranda C., Royo J. B., Abad F. J., Santesteban L.G., 2019. Evaluation of the agronomic performance of 'Syrah' and 'Tempranillo' when grafted on 12 rootstocks. Vitis, 58 (Special Issue), 111-118.

Miele A., Rizzon L.A., 2017. Rootstock-scion interaction: 2. Effect on the composition of Cabernet Sauvignon grape must. Rev. Bras. Frutic., v. 39, n.3: $(\mathrm{e}-434) . \quad$ Available at: https://ainfo.cnptia.embrapa.br/digital/bitstream/item/162797/1/201 7-v39-n3-p1-9-e-434.pdf (accessed on 14.07.2019).

Moreno-Sanz P., Loureiro M.D., Suárez B., 2011. Microsatellite characterization of grapevine (Vitis vinifera L.) genetic diversity in Asturias (Northern Spain). Sci. Hortic., 29, 433-440.

Naredo M., 1914. Elaboración y conservación de los vinos producidos en la provincia de Oviedo. Abonos minerales más convenientes al cultivo vitícola en las zonas de esta provincia Proc. National Congress Viticulture 1912. Navarra, Spain, 353356.

Neal S.M., Friend A.P., Trought M.C.T., McLachlan A.R.G., 2016 The performance of 'Sauvignon Blanc' on five grapevine rootstocks in a Marlborough vineyard. Acta Hort., 1115, 147-155.

Ollat N., Tandonnet J.P., Lafontaine M., Schultz H.R., 2003. Short and long term effects of three rootstocks on Cabernet Sauvignon vine behaviour and wine quality. Acta Hortic., 617, 95-99.

Picinelli A., Suárez B., Moreno J., Rodríguez R., Caso-García L.M., Mangas J.J. 2000. Chemical characterization of Asturian cider. J. Agric. Food Chem., 48, 3997-4002.

Ramos M. C., Jones G. V, Yuste J., 2018. Phenology of Tempranillo and Cabernet-Sauvignon varieties cultivated in the Ribera del Duero DO: observed variability and predictions under climate change scenarios. OENO One, 52, 31-44.

Renouf V., Tregoat O., Roby J.-P., van Leeuwen C., 2010. Soils, rootstocks and grapevine varieties in prestigious Bordeaux vineyards and their impact on yield and quality. J. Int. Sci. Vigne Vin, 44, 127-134.

Reynier A., 2005. Manual de viticultura. $6^{\text {th }}$ edition. 497 p. MundiPrensa (Ed.), Madrid, Spain.

Robinson J., Harding J., Vouillamoz J., 2012. Wine Grapes. A complete guide to 1,368 vine varieties, including their origins and flavours. 1248 p. Penguin (Ed.), UK.

Sabir A., Sahin Z., 2018. The Response of Soilless Grown 'Michele Palieri' (Vitis vinifera L.) Grapevine Cultivar to Deficit Irrigation Under the Effects of Different Rootstocks. ErwerbsObstbau, 60, 21-27.

Scalabrelli G., Ferroni G., D'Oofrio C., Di Collalto G., Venerini F., 2003. Trials with 'Sangiovese' grafted on several grapevine rootstocks in two different area of Tuscany. ActaHort., 617, 73-83.

Shellie K., Cragin J., Serpe M., 2014. Performance of Alternative European Wine Grape Cultivars in Southwestern Idaho: Cold Hardiness, Berry Maturity, and Yield. HortTechnology, 24, 138147 .

Sivilotti P., Zulini L., Petrussi C., Peterlunger E., 2007. Sensory properties of Cabernet Sauvignon wines as affected by rootstock and season. Acta Hortic, 754, 443-448.

Smart R., Robinson M., 1991. Sunlight into wine. A handbook for winegrape canopy management. 88 p. Winetitles (Ed.), Adelaide, Australia. 
Sousa M., Pereira C., Guerra J., Abade E., 2008. Caracterização de Castas Cultivadas na Região Vitivinícola de Trás-os-Montes Subregiões de Chaves, Planalto irandês e Valpaços. 48 p. Direcção Regional de Agricultura e Pescas do Norte (DRAPN) Núcleo de Documentação e Relações Públicas (NDRP) (Ed.), Mirandela, Portugal.

Spring J.L., Verdenal T., Zufferey V., Gindro K., Viret O., 2012. Influence du porte-greffe sur le comportement du cépage Cornalin dans le Valais central. Rev. Suisse Vitic. Arboric. Hortic., 44, 298307.

Spring J.L., Zufferey V., Verdenal T., Viret O., 2016. Influence du porte-greffe sur le comportement du Pinot noir dans les conditions du Valais central. Rev. Suisse Vitic. Arboric. Hortic., 48, 112-122.

Suárez B., Pando R., Fernández N., González A., Rodríguez R. 2005. Analitical differentiation of cider inoculated with yeast (Saccharomyces cerevisiae) isolated from Asturian (Spain) apple juices. LWT-Food Sci. Technol., 38, 455-461.

van Leeuwen C., Darriet P., 2016. The impact of climate change on viticulture and wine quality. J. Wine Econom., 11, 150-167.

van Leeuwen C., Destrac-Irvine A., 2017. Modified grape composition under climate change conditions requires adaptation in the vineyard. OENO One, 51, 147-154.

Vilanova M., Campo E., Escudero A., Graña M., Masa A., Cacho J., 2012. Volatile composition and sensory properties of Vitis vinifera red cultivars from North West Spain: Correlation between sensory and instrumental analysis. Anal. Chem. Acta, 720, 104-111.
Whiting J.R., 2003. Selection of grapevine rootstocks and clones for Greater Victoria. State of Victoria, Department of Primary Industries, Melbourne, Australia. Available at: http://www.hin.com.au/ data/assets/pdf file/0005/9149/Selectionof-rootstocks-and-clones-Whiting-2003.pdf (accessed on 20.09.2019).

Wooldridge J., Olivier M.P., 2014. Effects of weathered soil parent materials on Merlot grapevines grafted onto 110 Richter and 10114 Mgt rootstocks. S. Afr. J. Enol. Vitic., 35, 59-67.

Xiao Z., DeGaris K. A., Baby T., McLoughlin S. J., Holzapfel B. P., Walker R. R., Schmidtke L. M., Rogiers S. Y., 2020. Using rootstocks to lower berry potassium concentrations in 'Cabernet Sauvignon' grapevines. Vitis, 59, 117-126.

Yuste J., Vicente A., Barajas E., Albuquerque M., 2017. Diez portainjertos de vid: Efectos sobre el crecimiento, la producción y la composición de la uva del cv. Sauvignon blanc en la denominación de origen Rueda (España). BIO Web of Conferences 9, 01009. Proc. 40 ${ }^{\text {th }}$ World Congress of Vine and Wine, Sofia, Bulgary. Available at: https://www.bioconferences.org/articles/bioconf/pdf/2017/02/bioconfoiv2017 01009.pdf (accessed on 22.07.2019).

Zhang L., Marguerit E., Rossdeutsch L., Ollat N., Gambetta A.G., 2016. The influence of grapevine rootstocks on scion growth and drought resistance. Theor. Exp. Plant. Physiol., 28, 143-157. 